\title{
A Rework Reduction Model for Construction Projects
}

\author{
Peter E. D. Love, Zahir Irani, and David J. Edwards
}

\begin{abstract}
Rework is an endemic problem in building construction projects and is an area of research that has received limited attention. Recent research has shown that rework is the primary cause of time and schedule overruns in projects and that rework levels do not significantly differ between current procurement methods despite calls from government for the use of more integrated procurement approaches such as design-and-construct to improve project performance. To reduce the incidence of rework throughout the construction supply chain, data from 161 completed projects were gathered using a questionnaire survey. Stepwise multiple regression was used to determine the significant variables that contributed to rework in projects. In conjunction with previously reported research, these variables were used to develop an alternative procurement model for reducing rework in projects. It is suggested that the proposed model could be used to stimulate interorganizational relations and promote teambuilding during the formative stages of a project, which is essential for reducing design-related rework.
\end{abstract}

Index Terms-Change, construction, procurement model, rework, stepwise regression.

\section{INTRODUCTION}

$\mathbf{T}$ IME AND schedule overruns, quality deviations, and poor safety typically plague projects in the Australian construction industry [14], [20], [25]. In addition, there have been numerous government initiated reports that have criticized the industry for its fragmented nature, lack of coordination and communication between participants, adversarial contractual relationships, lack of a customer-supplier focus, price-based selection, and ineffective use of technology [6], [20], [43]. Such poor organizational and management practices have contributed to time wastage, unnecessary costs, increased errors, and misunderstandings, which have invariably resulted in rework occurring in projects [1], [13], [27]. Moreover, rework has been identified as the primary factor that contributes to time and schedule overruns in projects [33].

Delays and cost overruns are seemingly the rule rather than the exception in the construction industry [14]. Client design changes are frequent, generating costly ripple effects that create delay and disruption throughout the entire project supply chain [2]. Projects often appear to be going smoothly until near the end, when errors made earlier are discovered, necessitating

Manuscript received February 1, 2002; revised March 1, 2004. Review of this manuscript was arranged by Department Editors R. Balachandra and J. K. Pinto. This work was supported in part by the Australian Research Council under Grant DP-0453258.

P. E. D. Love is with the School of Management Information Systems, Edith Cowan University, Churchlands, Perth W.A. 6018, Australia (e-mail: p.love@ecu.edu.au).

Z. Irani is with the Department of Information Systems and Computing, Brunel University, Uxbridge, Middlesex UB8 3PH, U.K.

D. J. Edwards is with the Department of Civil and Building Engineering, Loughborough University, Loughborough, Leicestershire LE11 3TU, U.K.

Digital Object Identifier 10.1109/TEM.2004.835092 costly rework [17], [21], [34]. Such rework may result in overtime, additional hiring of resources, schedule slippage, or reductions in project scope or quality. The consequences of these difficulties include reduced profit, loss of market share and reputation, increased turnover of management and workforce, lower productivity, higher costs, and all too frequently costly litigation between participants over responsibility for overruns and delays. According to the Australian Procurement and Construction Comittee [6], various industry development initiatives have focused on addressing the symptoms rather the causes of the industry's problems. Thus, these problems must be understood in a holistic manner and to that end, it is, therefore, necessary to examine what actually happens in construction.

By gaining understanding of the mechanisms causing rework, then advancement toward its reduction in construction can be made. Previous studies have not been able to generalize the key factors that contribute to rework. The research presented in this paper, however, uses multiple stepwise regression to identify the significant variables that contributed to rework in 161 projects. In conjunction with previously reported research, these variables are used to develop an alternative procurement model that could be used to reduce rework in construction projects.

\section{REWORK IN BuILDing CONSTRUCTION PROJECTS}

Numerous studies have attempted to quantify the direct costs of rework, or its constituent components, in building and engineering projects [1], [8], [10], [13], [24], [33], [34]. These direct costs (of rework) have been found to range from $3 \%$ to $23 \%$ of contract value [8], [27], [33], [34]. In addition, the scope of these studies has been limited to a small sample often with only several projects, so the costs that have been reported are by no means representative. A number of factors have contributed to such large variances in these reported findings. These include, the extent of quality management practices implemented, the type of project, the form of procurement method used, and the level of project complexity. Research has, however, demonstrated rework costs do not significantly differ with the type of project and procurement method used [33]. While this may be the case, a contractor's estimate/tender figure will typically allow for some degree of rework (in the form of a contingency) based on their knowledge and experience from previous and similar projects that they have undertaken [35].

There has been a lack of uniformity in the way in which rework cost data has been collected, as there are various interpretations as to what constitutes rework exist [24]. For example, terms such as quality deviations [10], nonconformances [1], defects [27], and quality failures [8] are often used, though these definitions vary in scope. Ashford [4] defines rework as "the process by which an item is made to conform 
to the original requirement by completion or correction." The Construction Industry Development Agency [15], however, defined rework as "doing something at least one extra time due to nonconformance to requirements." Essentially, rework can arise from errors, omissions, failures, damage, and change orders that occur in projects [38].

\section{A. Review of Rework Causes}

The Building Research Establishment (BRE) in the U.K. [9] found that errors in buildings had $50 \%$ of their origin in the design stage and $40 \%$ in the construction stage. In 1987, the National Economic Development Office conducted a survey [41] that aimed to identify ways of improving quality control in building works. The main factors that influenced quality were attributed to design (e.g., lack of coordination of design, unclear and missing documentation) and poor workmanship (e.g., lack of care and knowledge).

It has been suggested that the use of constructability analysis could significantly reduce design and construction-related rework [36], [44]. Constructability is a strategy that can be used to achieve optimum integration of construction knowledge throughout the procurement process, as well as balance various project and environmental constraints so as to maximize project goals and building performance. This is done by using the knowledge and experience of key design and construction personnel during the design process so as to improve teamwork, and planning and scheduling of site operations, which in turn can translate into ameliorated project performance in terms of time, cost, and quality. Projects where constructability has been specifically addressed have reported savings of $6 \%-10 \%$ of construction costs [52]. Similarly, value management (VM) can also be used to minimize design changes and errors. However, this technique can be an additional, which many clients are often reluctant to pay for [40].

Burroughs [11] reported that a major Australian contractor had experienced rework costs that equated to $5 \%$ of the contract value during the construction of a major project; these costs were subsequently attributed to poor documentation produced by design consultants. Gardiner's [23] estimates are more alarming as they suggest that rework costs attributed to design consultants could be as high as $20 \%$ of their fee for a given project. Documentation quality may suffer when a firm submits a low design fee for a project, especially when design tasks are subject to "time boxing." That is, a fixed period of time may be allocated to complete each task, irrespective of whether the documentation or each individual task is complete or not.

Poor planning of workload within design organizations can also contribute to "time boxing" and result in inadequate time to prepare complete design documents [46] Moreover, the use of inexperienced staff that lack technical knowledge can also lead to errors and omissions in contract documentation being made [34]. Rounce [46] identified a number of poor management practices that contribute to the generation of rework and waste in architectural firms. These include the following:

- jobs not having projected drawing lists to quantify the design workload;
- jobs not having design programs based on project drawing lists and, therefore, specific design deliverables are unable to be identified;

- difficulty in estimating the physical progress of the design;

- uncertainty in advising other designers/quantity surveyors (QSs)/clients/contractors when information is likely to be available;

- difficulty in justifying resources required to in-house managers based on actual workload;

- lack of specific procedures (nonadministrative) generally to control the design process in program terms.

Increased client demands for earlier project completion is another factor that has been identified as a major contributing factor to the production of incomplete and/or erroneous contract documentation [34]. Lack of attention to management of the documentation process has lead to profits being eroded because rework has become a norm within architectural firms [23]. Specific rework activities that contribute to reducing profit levels in architectural firms include [46]:

- redesign due to an inadequate brief;

- changes arising from unchecked drawing issue;

- redesign due to inappropriate drawing scale;

- attending to design changes requested by the client.

Cooper [17] has suggested that the design of large construction projects may require up to two-and-a-half cycles of rework to "get it right." This finding clearly identifies that rework imposes a significant amount of additional time and cost on design consultants.

\section{B. Quality Management}

Findings published by the BRE [9] provided the impetus for examining how quality management can be used by design organizations during the early stages of a project. The BRE demonstrated that the introduction of quality management would help to realize significant cost benefits. Lomas [32] of Barclay Construction Ltd. (Australia) reported that prior to the implementation of quality assurance (QA) system, it was estimated that their rework costs were $5 \%$ of the contract value. However, subsequent to QA implementation, rework was reduced to less than $1 \%$ of contract value in almost all projects. Lomas [32] found that QA practices implemented, secured a company saving of $\$ A 4.2 \mathrm{~m}$ in 1996 , which equates to approximately $1 \%$ of their turnover.

\section{Client/Design Team}

Clients and their project team members must communicate and work together harmoniously if projects are to be delivered on or ahead of time. In particular, Sidwell [48] recognized the potential positive influence of client involvement in projects. By empowering clients in the design process change orders (specifically, design-related) during the construction phase can be minimized. Yet, this observation typically holds only for those clients who procure projects on a regular basis [39]. Design related rework in the form of change orders is the major source of rework in construction projects [10], [38]. A dearth in communication flow between the client and design team 
members can result in documentation errors and omissions occurring. Client and design team factors that have been identified as contributing to rework include [1], [8], [13], [27], [37], [39]:

- inadequate funding provided during site investigations;

- inadequate time and funds attributed to the briefing process;

- payment of low fees for preparing contract documentation

- ineffective use of information technology (e.g., visualization);

- poor design coordination between design team members.

\section{Site Management Team and Subcontractors}

Project success is dependent upon the effectiveness of the main contractor's (and their subcontractors and supplier) construction planning efforts (i.e., planning, coordination) [22]. Site management team must work with their subcontractors to plan the work that needs to be undertaken. Quality management (QM), particularly QA, can be used as a mechanism to ensure that appropriate controls are put in place to monitor work activities. Contractors and subcontractors have, however, been found to often "pay lip service" to QA because of the perceived increase in administration and additional work that is required [41]. Besides the ineffective use of QM by site management, other factors that contribute to rework include [37]-[39]:

- setting-out errors;

- staff turnover and reallocation to other projects;

- failure to provide protection to works.

In the case of subcontractors, specific factors that contribute to rework include [8], [27]:

- inadequate supervision;

- damage to other trades due to carelessness;

- low skill level;d

- poor use of materials.

\section{METHOD}

For the purposes of the research presented in this paper, rework is defined as "the unnecessary effort of redoing a process or activity that was incorrectly implemented the first time" [33]. A questionnaire was developed from the literature review to examine the influence of project management influences on rework costs in projects. Rather than developing a questionnaire survey that sought respondents' general opinions about rework, respondents were asked to select a recently completed project most familiar to them and to answer questions about the perceived causes of rework, associated costs, and the project management practices implemented. In essence, each project identified by respondents was treated as a separate case.

Respondents were asked to provide an estimate of rework (direct, that is, those costs that can be readily quantified and indirect, those that are cannot be quantified) costs incurred during the project that they had selected. Using a five-point Likert scale, respondents were asked to indicate their extent of agreement as to how much the identified factors contributed to the occurrence of rework. Respondents were also provided with an opportunity at the end of the questionnaire to provide supplementary information about why rework occurred in their selected project.

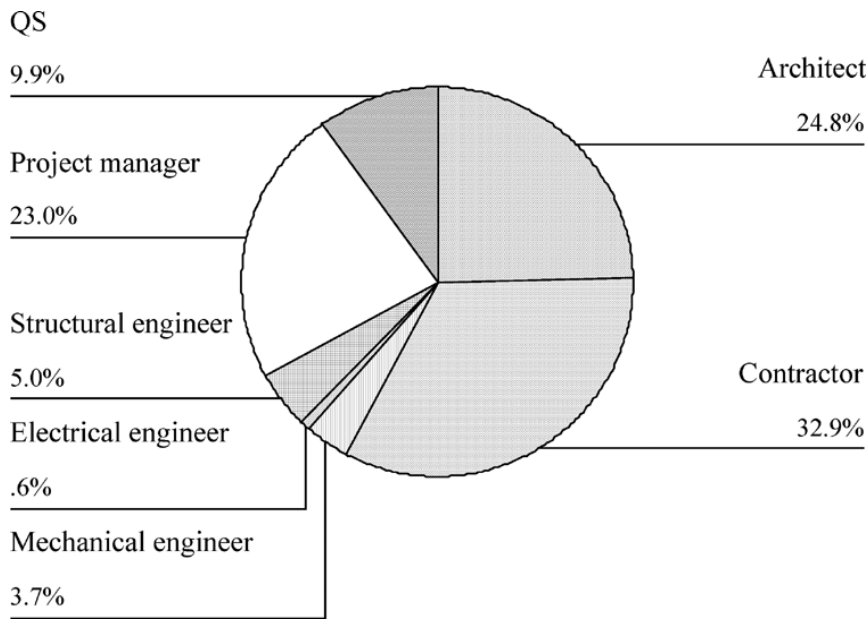

Fig. 1. Respondents by profession.

Stratified random sampling was used to select the study sample from the telephone directory, Yellow Pages by location. In addition, to increase the representativeness of samples, stratified random sampling was a useful technique that made general statements about the portions of the population possible. Prior to determining the sample size for the main study, a pilot survey was undertaken with 30 selected firms, which comprised of architects, project managers, and contractors from the Geelong and Melbourne region, in the State of Victoria, Australia. This was undertaken to test the potential response rate, suitability, and comprehensibility of the questionnaire. Each firm was contacted by telephone and informed of the research aims. On obtaining their consent, the questionnaire was mailed, with a stamped addressed return envelope enclosed, for respondents' returns. The respondents were also asked to critically review the survey's design and structure. A total of 25 responses were received (representing an $83 \%$ response rate) and positive feedback obtained indicated that the questionnaire should remain unaltered for the main survey. The composition of respondents that returned that questionnaire were architects $(30 \%)$, contractors $(50 \%)$, and project managers $(20 \%)$.

For the main survey, 420 questionnaires were distributed to industry practitioners throughout Australia. 136 valid responses were received from the main survey and were added to the pilot questionnaires to produce 161 valid responses in total (this represented a response rate of $36 \%$ ). This response rate was considered acceptable for a survey focusing on gaining responses from industry practitioners [3].

Fig. 1 provides a breakdown of the useable responses by respondent type. It can be seen that contractors, architects, and project managers accounted for approximately $81 \%$ of respondents. While it would appear that QSs, and structural, mechanical, and electrical engineers are under represented, it should be noted that many consultancy firms offer project management services and as a result may have undertaken a role of project manager for a project that they selected.

As there were low response rates from QSs and the engineering profession, respondents were recategorized under the following headings for analysis purposes: 


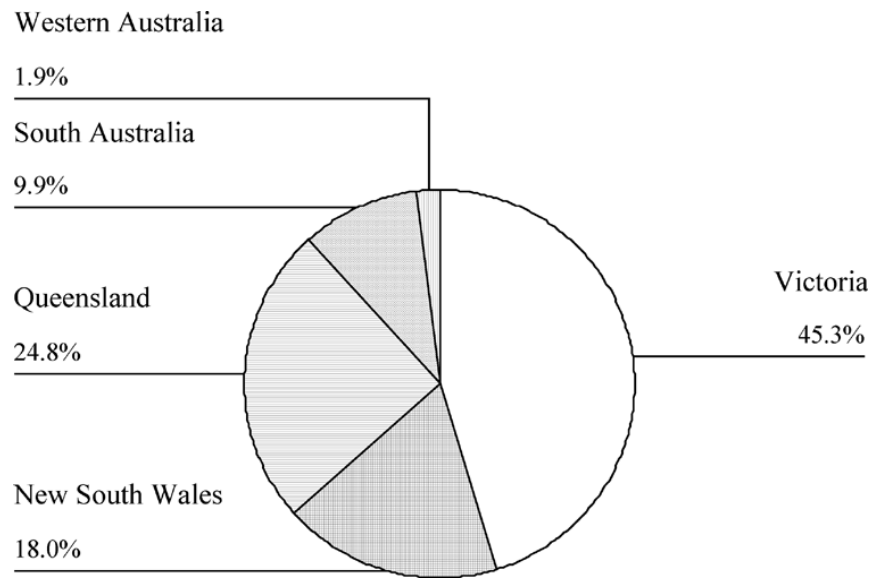

Fig. 2. Respondents by state.

TABLE I

DESCRIPTIVE STATISTICS FOR RESEARCH CONSTRUCTS

\begin{tabular}{lcccc}
\hline Constructs & $\begin{array}{c}\text { No of } \\
\text { Items }\end{array}$ & Mean & SD & $\alpha$ \\
\hline Design cost sources & 6 & 2.31 & 0.95 & 0.76 \\
Construction cost sources & 9 & 1.92 & 0.99 & 0.72 \\
Contract documentation & 5 & 2.58 & 1.07 & 0.75 \\
Client & 6 & 2.54 & 1.12 & 0.76 \\
Project communication & 6 & 2.97 & 1.07 & 0.84 \\
Project scope & 5 & 2.81 & 1.08 & 0.7 \\
Design team & 10 & 2.66 & 0.99 & 0.86 \\
Site management & 6 & 2.50 & 1.11 & 0.8 \\
Subcontractor & 5 & 2.22 & 0.98 & 0.83 \\
\hline
\end{tabular}

- design consultants, which comprised of architects, QSs, structural, mechanical and electrical engineers (44\%);

- contractors $(33 \%)$;

- project managers $(23 \%)$.

Fig. 2 provides a breakdown of respondents who answered the questionnaire by State. Considering the number of construction projects being undertaken in Australia at any one time, the likelihood of respondents selecting the same project was significantly reduced because of the diversity of data sources from each State. However, it should be acknowledged that respondents presented their own views of the project that they had been involved with and, therefore, may have attributed problems that could have been experienced to rework instead of some other reason.

\section{ANALYSIS}

Prior to undertaking the detailed analysis for each of the research constructs their reliability was determined by using the Cronbach's coefficient alpha $(\alpha)$. If the value $\alpha$ is greater than 0.70 , then the research construct is a considered to be a reliable measure [18]. The $\alpha$ levels, as well as the number of items used in the scale, for each of the project management constructs used in the questionnaire, can be seen in Table I and in Appendix A.

The $\alpha$ levels for the data indicate a moderately high degree of internal consistency (i.e., measures are related to the same construct) for the research instrument, which is a necessary condi- tion for construct validity [51]. In this instance, the constructs for which data were gathered by the research instrument are measures for rework causes. Considering the limited empirical research that has addressed the problem of rework in construction projects and the attained $\alpha$ levels, the questionnaire survey has demonstrated that it is a reliable research instrument.

A measure has content validity if there is general agreement among subjects and researchers that the instrument has measurement items that cover all aspects of the variable being measured. Content validity was not evaluated numerically, but subjectively judged by the researchers. The measures of the constructs developed for this paper have content validity, since the selection of measurement items were derived from the literature [37]-[39]. Furthermore, pretest subjects indicated that the content of each factor was represented by the measurement instruments employed.

One-way analysis of the variance, two-tailed (ANOVA) was used to compare the means of respondents' estimates for rework costs (direct and indirect) and to determine if there were any significant differences among them. A Kruskall-Wallis test was undertaken to determine if there significant differences in respondents' perceptions of rework causes for each of the constructs identified in Table I. This test was undertaken because variables had a continuous distribution and measured using an ordinal scale of measurement. To examine the relationship between total rework costs (TRCs) and the independent variables (IVs), stepwise regression was used. Stepwise regression has an advantage over other multivariate techniques in terms of the number of potential subset models checked before the model for each subset is decided. Consequently, there is a greater chance of choosing the best subsets in the sample data when there are a large number of potentially relevant regressor variables [45].

\section{RESULtS}

\section{A. Rework Costs}

Rework costs are very rarely, if ever, measured by Australian construction organizations [35] so the estimates provided by respondents were based on subjective evaluations and their personal knowledge of the project. Tables II and III provide a summary of facility types and the procurement methods used in the projects sampled. The TRCs were calculated by adding the direct and indirect estimates provided by the respondents (Table IV). The mean ( $\underline{\mathrm{M}})$ and standard deviation $(\underline{\mathrm{SD}})$ of TRC for the 161 construction projects were $12.0 \%$ and $13.56 \%$, respectively. Respondents' estimates for direct rework costs were $\underline{\mathrm{M}}=6.4 \%, \underline{\mathrm{SD}}=7.78 \%$, and for indirect rework costs to be, $\underline{\mathrm{M}}=5.6 \%, \underline{\mathrm{SD}}=7.19 \%$ (Table V).

TRCs were found to vary considerably between projects (Tables V and VI). Some respondents reported rework costs to be less than $1 \%$ of a project's original contract value, while others have reported them to be as high as $80 \%$. The degree of variability in the estimates given by the respondents suggests that many respondents may be unsure about the actual costs of rework that were incurred in the projects that they selected.

Direct Rework Costs: The descriptive statistics revealed that there were differences between the design consultants $(\underline{\mathrm{M}}=$ $8.0 \%, \underline{\mathrm{SD}}=9.3 \%)$, contractor $(\underline{\mathrm{M}}=5.8 \%, \underline{\mathrm{SD}}=7.2 \%)$, and 
TABLE II

Procurement Methods Used to Deliver Project Types

\begin{tabular}{|c|c|c|c|c|c|c|c|c|c|c|c|c|}
\hline Project Type & & 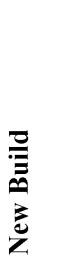 & 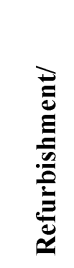 & 咅 & & 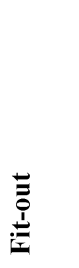 & $\frac{\partial}{\stackrel{\partial}{\bar{A}}}$ & 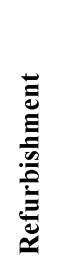 & 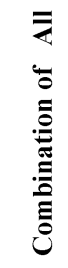 & & Total & \\
\hline Procurement Method & No. & $\%$ & No. & $\%$ & No. & $\%$ & No. & $\%$ & No. & $\%$ & No. & $\%$ \\
\hline Traditional & 40 & 44.4 & 31 & 72.0 & 5 & 35.7 & 7 & 63.6 & 1 & 33.3 & 84 & $\overline{52.2}$ \\
\hline $\begin{array}{l}\text { lump sum } \\
\text { Traditional }\end{array}$ & 1 & 1.1 & - & - & - & - & - & - & - & - & 1 & 0.6 \\
\hline $\begin{array}{l}\text { cost plus } \\
\text { Traditional with } \\
\text { provisional quants. }\end{array}$ & 5 & 5.6 & - & - & - & & - & - & - & - & 5 & 3.1 \\
\hline Design and & 1 & 1.1 & - & - & 1 & 7.1 & - & - & - & - & 2 & 1.2 \\
\hline $\begin{array}{l}\text { manage } \\
\text { Construction } \\
\text { management }\end{array}$ & 11 & 12.2 & 6 & 14.0 & 6 & 42.9 & 3 & 27.3 & - & - & 26 & 16.1 \\
\hline $\begin{array}{l}\text { Management } \\
\text { contracting }\end{array}$ & 1 & 1.1 & - & - & - & - & - & - & - & - & 1 & 0.6 \\
\hline Design and & 22 & 24.4 & 6 & 14.0 & 2 & 14.3 & 1 & 9.1 & 1 & 33.3 & 32 & 19.9 \\
\hline $\begin{array}{l}\text { build } \\
\text { Novation }\end{array}$ & 5 & 5.6 & - & - & - & - & - & - & 1 & 33.3 & 6 & 3.7 \\
\hline $\begin{array}{l}\text { Turnkey/package } \\
\text { deal }\end{array}$ & 2 & 2.2 & - & - & - & - & - & - & - & - & 2 & 1.2 \\
\hline BOOT & 2 & 2.2 & - & - & - & - & - & - & - & - & 2 & 1.2 \\
\hline Total & 90 & 100 & 43 & 100 & 14 & 100 & 11 & 100 & 3 & 100 & 161 & 100 \\
\hline
\end{tabular}

project manager $(\underline{\mathrm{M}}=4.3 \%, \underline{\mathrm{SD}}=3.9 \%)$ in their estimates of direct rework costs. Levene's test of homogeneity of variances was violated $(p<0.05)$, which indicates that the population variances for each respondent type were not equal. The ANOVA revealed significant differences between respondents estimates of direct rework costs $F(2,158)=3.028, p<0.05$. The results of Tukey's HSD post-hoc test identified that the differences in the estimates for direct rework costs were between design consultants and project managers $(p<0.05)$.

Consultant project managers typically act as the client's representative for projects and, thus, would possess reasonable knowledge to be familiar with the direct rework costs (in the form of change orders and defects), as they invariably manage time and cost schedules. Project managers, however, may not be aware of the direct rework costs associated with redocumenting aspects of the project after clients have requested design changes and/or omissions. While client involvement in projects has been identified as a factor that can contribute to project success [34], [48], their involvement may also contribute to the occurrence of rework [37]. For example, drawing on the qualitative comments that were provided by the respondents, a project manager stated that the "client was a decision-maker and actively involved in construction, resulting in scope and design changes throughout the construction." This in turn can lead to design consultants having to redocument or provide additional documentation, which can significantly affect their fee, as they are often not reimbursed for this service [37].

Several design consultants articulated this point, with one stating "reworking of documentation is becoming a common occurrence on projects, which is not reflected in our fee." Another design consultant stated "a lot of rework had to be done on the documentation to reduce the scope of packages or substitute materials in an attempt to get the project within the budget." Redocumentation due to design changes and omissions initiated by clients and end-users appears to be a regular occurrence in Australian projects [34], [37]. The allocation of resources and planning of the documentation process are important points that need to be addressed if rework is to be reduced. Yet, understanding why there are differences in the estimates of direct rework costs is a major research task in itself and, thus, worthy of further investigation. Though, it would appear that consultant project managers might not fully understand how changes/omissions could affect the performance of design consultants (particularly, the way in which they manage the documentation process) and as such explain the differences in the estimates for direct rework costs.

Indirect Rework Costs: The descriptive statistics revealed that there were differences between the design consultants $(\underline{\mathrm{M}}=6.77 \%, \underline{\mathrm{SD}}=8.34 \%)$, contractors $(\mathrm{M}=5.46, \% \underline{\mathrm{SD}}=$ $6.87 \%)$, and project managers $(\underline{\mathrm{M}}=3.64 \%, \underline{\mathrm{SD}}=4.37 \%)$ 
TABLE III

TYPE OF FACILITY AND PROJECT PROCURED

\begin{tabular}{|c|c|c|c|c|c|c|c|c|c|c|c|c|}
\hline Project Type & & $\begin{array}{l}\text { 믈 } \\
\text { 量 } \\
\text { z }\end{array}$ & 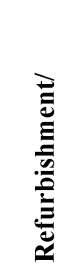 & 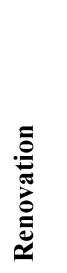 & & 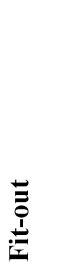 & 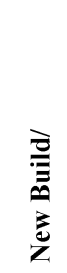 & 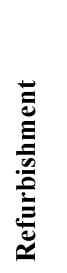 & 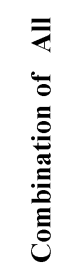 & & Tota & \\
\hline Facility Type & No. & $\%$ & No. & $\%$ & No. & $\%$ & No. & $\%$ & No. & $\%$ & No. & $\%$ \\
\hline Adminis trative & 3 & 3.3 & 3 & 7.0 & 2 & 14.3 & - & - & - & - & 8 & 5 \\
\hline $\begin{array}{l}\text { Authorities } \\
\text { Administrative }\end{array}$ & 8 & 8.9 & 2 & 4.7 & 2 & 14.3 & - & - & - & - & 12 & 7.5 \\
\hline $\begin{array}{l}\text { Civic } \\
\text { Banks }\end{array}$ & 1 & 1.1 & 2 & 4.7 & - & - & 2 & 18.2 & - & - & 5 & 3.1 \\
\hline Educational & 3 & 3.3 & 2 & 4.7 & - & - & - & - & - & - & 5 & 3.1 \\
\hline $\begin{array}{l}\text { School } \\
\text { Educational }\end{array}$ & 6 & 6.7 & 3 & 7.0 & - & - & 2 & 18.2 & 1 & 33.3 & 12 & 7.5 \\
\hline $\begin{array}{l}\text { University } \\
\text { Entertainment }\end{array}$ & 5 & 5.6 & 1 & 2.3 & 1 & 7.1 & - & - & - & - & 7 & 4.3 \\
\hline Hotel/Motel/Resort & 11 & 12.2 & 1 & 2.3 & 1 & 7.1 & - & - & - & - & 13 & 8.1 \\
\hline Hospitals/Health & 10 & 11.1 & 4 & 9.3 & 1 & 7.1 & 5 & 45.5 & - & & 20 & 12.4 \\
\hline Commercial & 9 & 10 & 2 & 4.7 & 1 & 7.1 & - & - & - & - & 12 & 7.5 \\
\hline $\begin{array}{l}\text { Recreational } \\
\text { Commercial Retail }\end{array}$ & 7 & 7.8 & 5 & 11.6 & 2 & 14.3 & 1 & 9.1 & 1 & 33.3 & 16 & 9.9 \\
\hline Commercial & 8 & 8.9 & 9 & 20.9 & 3 & 21.4 & 1 & 9.1 & 1 & 33.3 & 22 & 13.7 \\
\hline $\begin{array}{l}\text { Offices } \\
\text { Industrial }\end{array}$ & - & - & 1 & 2.3 & 1 & 7.1 & - & - & - & - & 2 & 1.2 \\
\hline $\begin{array}{l}\text { Warehouses } \\
\text { Industrial Factory }\end{array}$ & 2 & 2.2 & 2 & 4.7 & - & - & - & - & - & - & 4 & 2.5 \\
\hline Residential & 16 & 17.8 & 5 & 11.6 & - & - & - & - & - & - & 21 & 13 \\
\hline Airport & 1 & 1.1 & 1 & 2.3 & - & - & - & - & - & - & 2 & 1.2 \\
\hline Total & 90 & 100 & 43 & 100 & 14 & 100 & 11 & 100 & 3 & 100 & 161 & 100 \\
\hline
\end{tabular}

in their estimates of indirect rework costs. Levene's test of homogeneity of variances was not violated $(p<0.05)$, which indicates that the population variances for each group were equal. The ANOVA test revealed that there were no significant differences between respondents' estimates for indirect rework costs $F(2,158)=2.364, p<0.05$. Noteworthy, design consultants' estimates are almost twice as much as those estimated by project managers, which again demonstrates the variability associated with rework cost estimates, albeit not for the same projects.

When respondents were asked to compare the rework costs of their selected project with others that they had been involved with, $12 \%$ stated that they were comparable to a "very large extent," $16 \%$ "to large extent," 37 "to some extent," $26 \%$ to a minor extent, and 9\% "not at all." The mode was found to be "to some extent" and, thus, it can be concluded that the estimated rework costs reported are generally representative of industry practice in Australia.

The rework costs found from this research appear to be relatively comparable with previous studies [1], [8], [10], [27]. However, such studies, with the exception of Barber et al. [8] fail to differentiate or acknowledge a distinction between direct and indirect costs. Thus, the mean rework costs (direct and indirect) reported are considered benchmarks that could be used to pursue best practice in the Australian and international construction industry.

\section{B. Rework Causes}

The analysis revealed no significant differences between respondents' rankings as to the cost source and causes of rework 
TABLE IV

DIRECT AND INDIRECT REWORK COST ESTIMATES BY RESPONDENT TYPE

\begin{tabular}{|c|c|c|c|c|c|c|c|c|c|c|c|}
\hline \multirow[b]{3}{*}{ Respondent } & \multirow{2}{*}{\multicolumn{6}{|c|}{ Direct Rework Costs }} & \multirow{2}{*}{\multicolumn{5}{|c|}{ Indirect Rework Costs }} \\
\hline & & & & & & & & & & & \\
\hline & $\mathbf{N}$ & Mean & $\begin{array}{c}\text { Std. } \\
\text { Deviation }\end{array}$ & $\begin{array}{c}\text { Std. } \\
\text { Error }\end{array}$ & Min & Max & Mean & $\begin{array}{c}\text { Std. } \\
\text { Deviation }\end{array}$ & $\begin{array}{c}\text { Std. } \\
\text { Error }\end{array}$ & Min & $\overline{\operatorname{Max}}$ \\
\hline Design Consultant & 71 & 8.0 & 9.3 & 1.1 & 0.50 & 50.00 & 6.77 & 8.34 & 0.99 & 0.00 & 50.00 \\
\hline Contractor & 53 & 5.8 & 7.2 & 1.0 & 0.10 & 30.00 & 5.46 & 6.87 & 0.94 & 0.00 & 30.00 \\
\hline Project Manager & 37 & 4.3 & 3.9 & 0.6 & 0.50 & 15.00 & 3.64 & 4.37 & 0.71 & 0.00 & 20.00 \\
\hline Total & 161 & 6.4 & 7.8 & 0.6 & 0.10 & 50.00 & 5.62 & 7.18 & 0.56 & 0.00 & 50.00 \\
\hline
\end{tabular}

TABLE V

DiRECT AND INDIRECT REWORK COSTS FOR PROCUREMENT METHODS USED

\begin{tabular}{|c|c|c|c|c|c|c|c|c|c|c|c|}
\hline & & \multirow{2}{*}{\multicolumn{5}{|c|}{ Direct Rework Costs }} & & & & & \\
\hline \multirow[b]{2}{*}{$\begin{array}{l}\text { Procurement } \\
\text { Method }\end{array}$} & \multirow[b]{2}{*}{$\mathbf{N}$} & & & & & & \multicolumn{5}{|c|}{ Indirect Rework Costs } \\
\hline & & Mean & $\begin{array}{c}\text { Std. } \\
\text { Deviation }\end{array}$ & $\begin{array}{l}\text { Std. } \\
\text { Error }\end{array}$ & Min & Max & Mean & $\begin{array}{c}\text { Std. } \\
\text { Deviation }\end{array}$ & $\begin{array}{l}\text { Std. } \\
\text { Error }\end{array}$ & Min & $\overline{\operatorname{Max}}$ \\
\hline $\begin{array}{l}\text { Traditional lump } \\
\text { sum }\end{array}$ & 84 & 7.03 & 8.27 & 0.90 & 0.50 & 50.00 & 5.63 & 6.61 & 0.72 & 0.00 & 30.00 \\
\hline $\begin{array}{l}\text { Traditional cost } \\
\text { plus }\end{array}$ & 1 & 20 & - & - & 20.00 & 20.00 & 10.0 & - & 2.76 & 10.00 & 10.00 \\
\hline $\begin{array}{l}\text { Traditional with } \\
\text { provisional quants }\end{array}$ & 5 & 10 & 14.28 & 6.38 & 1.00 & 35.00 & 4.50 & 6.18 & 1.00 & 0.00 & 15.00 \\
\hline Design and manage & 2 & 5.5 & 6.36 & 4.50 & 1.00 & 10.00 & 1.0 & 1.14 & 1.11 & 0.00 & 2.00 \\
\hline $\begin{array}{l}\text { Construction } \\
\text { management }\end{array}$ & 26 & 4.11 & 4.15 & 0.81 & 0.50 & 15.00 & 4.48 & 5.67 & 1.65 & 0.00 & 20.00 \\
\hline $\begin{array}{l}\text { Management } \\
\text { contracting }\end{array}$ & 1 & 2.0 & - & & 2.00 & 2.00 & 0.0 & - & - & 0.00 & 0.00 \\
\hline Design and build & 32 & 5.90 & 7.11 & 1.25 & 0.10 & 30.00 & 6.29 & 9.38 & & 0.00 & 50.00 \\
\hline Novation & 6 & 9.16 & 11.02 & 4.49 & 0.50 & 30.00 & 9.91 & 10.44 & 4.26 & 0.50 & 25.00 \\
\hline $\begin{array}{l}\text { Turnkey and } \\
\text { package deal }\end{array}$ & 2 & 4.70 & 0.42 & 0.30 & 4.40 & 5.00 & 8.0 & 9.89 & 7.00 & 1.00 & 15.00 \\
\hline BOOT & 2 & 1.5 & 0.70 & 0.50 & 1.00 & 2.00 & 2.0 & 1.41 & 1.00 & 1.00 & 3.00 \\
\hline Total & 161 & 6.44 & 7.78 & 0.61 & 0.10 & 50.00 & 5.62 & 7.18 & 0.56 & 0.00 & 50.00 \\
\hline
\end{tabular}

for the following constructs: construction cost sources, client causes, subcontractor causes, and project scope $(\mathrm{p}<0.05)$. However, differences in respondents' rankings for design cost sources of rework were found $(p<0.05)$. These differences were "omission of items from the contract documentation" $\left(\chi^{2}=26.03, p=0.00\right)$ and "errors made in contract documentation" ( $\left.\chi^{2}=21.85, p=0.01\right)$. Design consultants generally considered contract documentation to be adequate for its intended purpose. In spite of the likely bias of designer consultants, both project managers and contractors considered contract documentation to be problematic. For example, one project manager stated "the design documentation was pathetic and incomplete at the time of tender." The project that the contractor was referring to was a design and construct (D\&C) project and as a result, they were deemed to bear the associated project risks. Yet, there is no obvious explanation as to why designers produce contract documentation with errors and omissions. A plausible explanation as to why documentation is so poor may be attributable to the fees they are charging. Irrespective of the fee, design consultants should act in a professional manner if they offer to do the required work (voluntarily or by bidding) and provide a quality service to their clients.

Design Team: There were differences between respondents as to the perceived design-team causes of rework. The analysis revealed that there were significant differences between respondents with respect to the "ineffective use of quality management practices" $\left(\chi^{2}=17.00, p=0.01\right)$, "time boxing" $\left(\chi^{2}=14.82, p=0.02\right)$, "incomplete design at the time of tender" $\left(\chi^{2}=14.42, p=0.02\right)$, and "poor coordination between design team members" ( $\left.\chi^{2}=15.00, p=0.02\right)$. It would 
TABLE VI

DiRECT AND INDIRECT REWORK COSTS FOR PROJECT TYPES

\begin{tabular}{|c|c|c|c|c|c|c|c|c|c|c|c|}
\hline \multirow[b]{3}{*}{ Project Type } & & & & & & & & & & & \\
\hline & & \multicolumn{5}{|c|}{ Direct Rework Costs } & \multicolumn{5}{|c|}{ Indirect Rework Costs } \\
\hline & $\mathbf{N}$ & Mean & $\begin{array}{c}\text { Std. } \\
\text { Deviation }\end{array}$ & $\begin{array}{l}\text { Std. } \\
\text { Error }\end{array}$ & Min & Max & Mean & $\begin{array}{c}\text { Std. } \\
\text { Deviation }\end{array}$ & $\begin{array}{l}\text { Std. } \\
\text { Error }\end{array}$ & Min & Max \\
\hline New build & 90 & 6.10 & 7.18 & 0.75 & 0.10 & 35.00 & 5.69 & 7.70 & 0.81 & 0.00 & 50.00 \\
\hline Refurb/Reno & 43 & 7.29 & 9.73 & 1.48 & 0.50 & 50.00 & 5.60 & 6.43 & 0.98 & 0.00 & 30.00 \\
\hline Fit-out & 14 & 7.78 & 7.70 & 2.06 & 1.00 & 30.00 & 6.10 & 7.90 & 2.11 & 0.50 & 30.00 \\
\hline Build/Refurb & 11 & 4.95 & 4.67 & 1.41 & 0.50 & 15.00 & 5.81 & 5.92 & 1.78 & 0.00 & 20.00 \\
\hline ination of all & 3 & 3.33 & 1.52 & 0.88 & 2.00 & 5.00 & 0.66 & 0.577 & 0.33 & 0.00 & 1.00 \\
\hline Total & 161 & 6.44 & 7.78 & 0.61 & 0.10 & 50.00 & 5.62 & 7.18 & 0.56 & 0.00 & 50.00 \\
\hline
\end{tabular}

appear that the design causes of rework in projects are exogenous to design consultants. Consequently, their quality procedures and systems are unable to control these variables. Needless to say firms do have control over the quality management systems and the management practices used to produce contract documentation. "Incomplete design at the time of tender" was identified as a prominent cause by contractors and project managers, but not by design consultants. This would, however, appear to be the case in most projects, as there is increasing pressure for firms to maximize their fee and, thus, revert to "time boxing." This practice places enormous pressure on staff, particularly if workload is not well planned and there is a high degree of staff turnover for the project. Naturally, if such practices prevail rework will be inevitable.

Site Management Causes: Significant differences were revealed between respondents with respect to mean rank of "poor planning and coordination of resources" $\left(\chi^{2}=19.41, p=\right.$ 0.04). In some instances, "poor planning and coordination of resources" may result in the contractor requesting changes so they can meet project objectives, for example, schedule and cost. Such changes may require redocumentation to some parts of project, which will invariably have an impact on the productivity and costs of the design consultant. Notably, the perceived causes of rework generally focus on the production and management of contract documentation, which is the responsibility of design team members. It has been noted by several researchers that poor contract documentation is also a major factor contributing to contractual claims in projects [37], [46].

\section{Design Management and Procurement Strategies}

Effective precontract project management, otherwise known as design management, can significantly reduce changes, errors, and omissions once construction has commenced. Consequently, respondents were asked to identify the types of design management and procurement strategies that had been implemented in their selected project, and then using a five-point Likert scale, were " $1=$ ineffective" and " $5=$ highly," their effectiveness in reducing the incidence of rework (Table VII).

Surprisingly, respondents did not identify any other strategies than those identified in Table VII. Many of the strategies identified did not form an integral part of a project's delivery strategy,
TABLE VII

DESCRIPTIVE STATISTICS FOR DESIGN MANAGEMENT AND PROCUREMENT STRATEGIES IMPLEMENTED

\begin{tabular}{lcccc}
\hline Procurement Strategy & N & \% & Mean & SD \\
\hline Contractual incentives & 58 & 36 & 2.69 & 1.30 \\
Project quality management system & 111 & 69 & 2.67 & 0.97 \\
Pre-qualification & 99 & 62 & 3.10 & 1.12 \\
Relational contracting & 56 & 35 & 2.98 & 1.09 \\
Bills of quantities (ASMM 5) & 76 & 47 & 2.64 & 1.22 \\
Design Management Strategy & & & & \\
Value management & 88 & 55 & 3.02 & 1.11 \\
Design for construction & 88 & 55 & 3.06 & 1.09 \\
Computer visualisation & 66 & 41 & 2.58 & 1.12 \\
Subcontractor/supplier involvement in & 81 & 50 & 2.89 & 1.11 \\
design & & & & \\
Constructability analysis & 84 & 52 & 3.12 & 0.97 \\
Design scope freezing & 77 & 48 & 2.92 & 1.11 \\
Team building & 75 & 47 & 3.25 & 0.97 \\
\hline
\end{tabular}

particularly, relational contracting. In addition, the use of computer visualization by design firms is still in its infancy in Australia, as many consider it to be an extra service for which clients need to pay [30]. Therefore, it is not surprising to see this design management strategy only being utilized in a small number of projects.

\section{Predictors of Rework}

The stepwise multiple regression analysis was performed using SPSS (Version 10.00) REGRESSION and SPSS FREQUENCIES for evaluation of assumptions. Variables required no transformations to reduce skewness, reduce outliers and improve normality, linearity, and homoscedasticity of residuals. This ensured that any models produced could be interpreted from the variable scales directly and without further manipulation [51]. With the use of a $p<0.001$ criterion, for Mahalanobis distance identified one multivariate outlier, $\chi^{2}(18)=40.790$. Similarly, Cook's $d<1$ identified four outliers that influence the precision of the estimation of the regression weights and were subsequently left in because their deletion would not have significantly affected them. The test for multicollinearity 
TABLE VIII

Multiple Stepwise Multiple REgRession ANALYsis

\begin{tabular}{llccccccc}
\hline Model & Variable & $\mathbf{B}$ & $\begin{array}{c}\text { Std. } \\
\text { Error }\end{array}$ & $\beta$ & $\mathbf{s r}_{\mathbf{i}}^{\mathbf{2}}$ & $\mathbf{R}$ & $\begin{array}{c}\mathbf{R}^{2} \\
\text { Adjusted } \\
\mathbf{R}^{\mathbf{2}}\end{array}$ \\
\hline 1 & (Constant) & 0.45 & 5.24 & & & & & \\
& CCAUSE_4 & 5.47 & 1.86 & 0.57 & 0.57 & 0.57 & 0.36 & 0.29 \\
\hline 2 & (Constant) & 9.35 & 6.29 & & & & & \\
& CCAUSE_4 & 5.83 & 1.70 & 0.60 & 0.64 & & & \\
& DESMAN_1 & -3.71 & 1.71 & -0.35 & -0.47 & 0.68 & 0.47 & 0.41 \\
\hline 3 & (Constant) & 35.17 & 8.52 & & & & & \\
& CCAUSE_4 & 4.71 & 1.33 & 0.50 & 0.66 & & & \\
& DESMAN_1 & -5.75 & 1.42 & -0.60 & -0.71 & & & \\
& PMDESN_2 & 5.94 & 1.65 & 0.55 & 0.67 & 0.84 & 0.71 & 0.66 \\
\hline 4 & (Constant) & 31.55 & 7.79 & & & & & \\
& CCAUSE_4 & 4.50 & 1.19 & 0.47 & 0.70 & & & \\
& DESMAN_1 & -6.92 & 1.37 & -0.72 & -0.80 & & & \\
& PMDESN_2 & 6.48 & 1.47 & 0.60 & 0.75 & & & \\
& DESMAN_6 & 3.32 & 1.48 & 0.29 & 0.50 & 0.87 & 0.78 & 0.73 \\
\hline
\end{tabular}

revealed that variables were not highly correlated with one another $(p>0.9)$. No cases had missing data and no suppressor variables were found $n=161$.

Regression was performed between TRCs and the project management practice variables identified in the Appendix A. It can be seen from Table VIII that four models were identified as being significant. Four of the 87 variables, namely, CCAUSE_4 (changes initiated by a client or occupier when a product or process had been completed), DESMAN_1 (value management), PMDESN_2 (ineffective use of information technology by the design team), and DESMAN_6 (design scope freezing) were found to significantly contribute to regression $(p<0.01)$. Semi-partial correlations were $s r_{i}^{2}=0.57$ CCAUSE_1, $s r_{i}^{2}=-0.47$ DESMAN_1, $s r_{i}^{2}=-0.67$ PMDESN_2, and $s r_{i}^{2}=0.50$ for DESMAN_6. Considering that all the four variables, particularly, DESMAN_1, make a significant contribution to the regression analysis, model $4, R^{2}=0.78$, $F(4,156)=13.65, p<0.01$ is the most appropriate, as it explains $78 \%$ of the variability in rework costs (Table VIII). The regression equation is expressed as

$$
\begin{aligned}
\text { TRC }= & 31.55+4.5 \text { (Client Changes) } \\
& -6.92 \text { (Value Management) } \\
& +6.48 \text { (Ineffective use of information technology) } \\
& +3.32 \text { (Design Scope Freezing). }
\end{aligned}
$$

Value management is a technique that can be used to reevaluate the functionality and the requirements of clients and, thus, can be used to minimize client-initiated changes, which may occur downstream during construction. Model 4 notes that the ineffective application of IT by design team members (PMDESN_2) contributes to rework in projects. Additionally, the ineffective use of information technology, specifically lack of interoperability, can lead to inappropriate and nontimely information transfer between design team members, and resultantly impose significant restrictions on decision-making. When information technology is used effectively by design team members it can improve information flow and communication, decision-making, design coordination, and be used to monitor changes in projects.

While it has been posited by the Construction Industry Institute (CII) [16] that "design scope freezing" (DESMAN_6) can result in the minimization of changes in projects, this research has identified that, as a factor, it can contribute to changes in the context of rework. When clients or occupiers, especially, inexperienced clients, are confronted with a design scope freeze, they may feel intimidated, as it reduces their decision-making flexibility about their final investment. If project scope is not adequately defined and specific client (or occupier) needs determined by the time that contract documentation is finalized, then necessary changes during construction may result in rework, which may have detrimental consequences on project cost and schedule. Notwithstanding this proposition, it is proffered that design scope freezing may ameliorate the likelihood of rework occurring in projects if used in conjunction with a rigorous and structured project scoping program that encapsulates a change control program, a constructability analysis, and value management workshop.

The analysis of rework costs clearly indicates it is a major source of cost growth in projects and that its needs to be reduced if project performance is to be improved. Moreover, the results of the analysis concur with previous studies that have investigated the causes of change orders in construction [19], [47], [53]. This is not surprising as changes, whether they are initiated by the client, contractor, or design team members, were identified as causes of rework. However, the fact remains that projects are experiencing considerable amounts of change, which invariably result in rework, even though techniques for managing and controlling its occurrence are well-known amongst project managers. This is perhaps because many construction organizations focus on preparing the next bid and project, and as such, no time is allowed for reflection, which is a critical part of the learning process. 


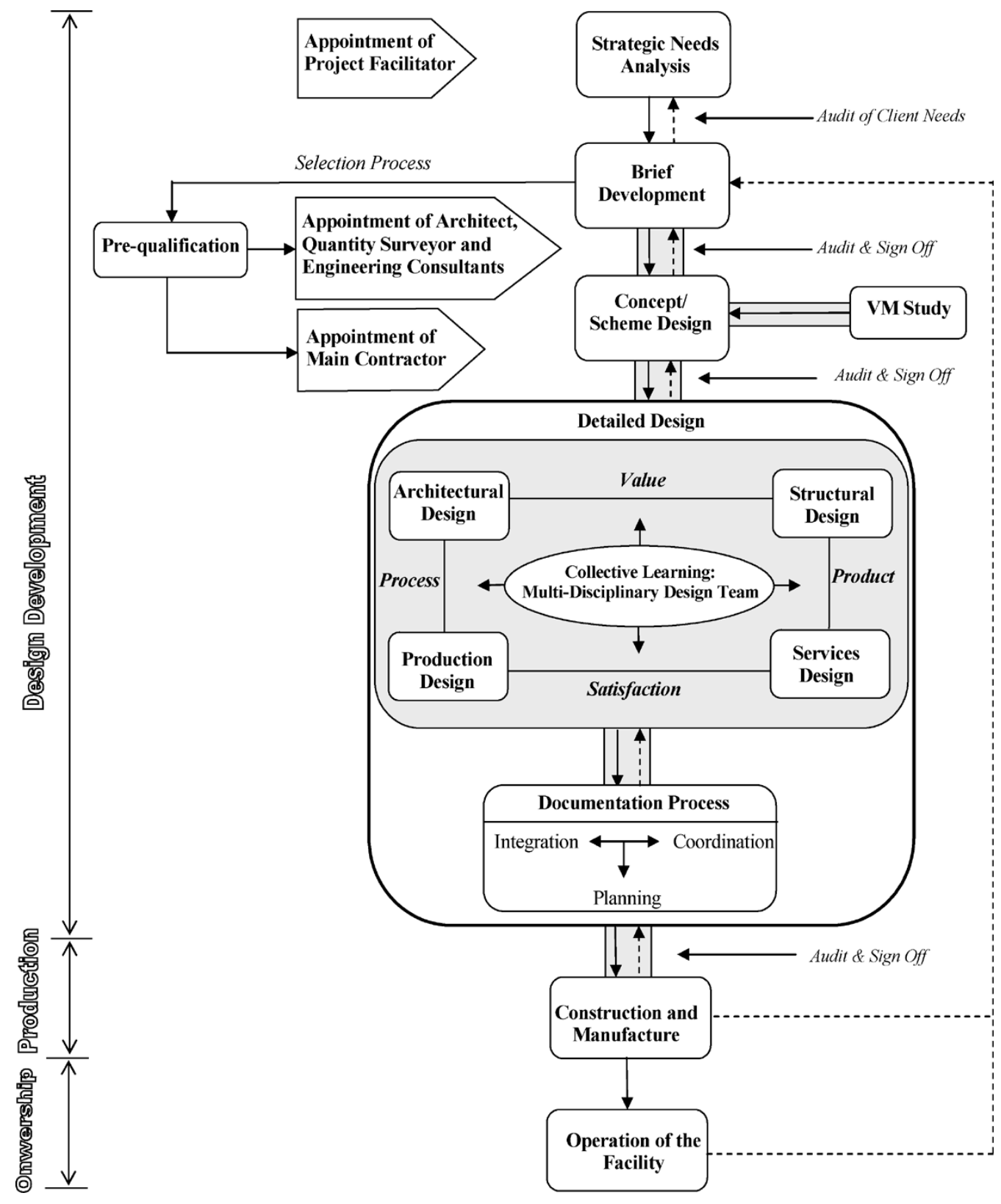

Fig. 3. Procurement model for reducing rework.

\section{PROCUREMENT MODEL FOR REWORK REDUCTION}

The analysis has identified a number of factors that need to be considered if rework is to be reduced in projects. Key causes of rework relate to the production and management of contract documentation, client initiated changes, and the ineffective use of information technology between design team members. Notably, no major contributors of rework were identified as originating from the site management team and subcontractors. Nonetheless, planning and coordination of resources is an area that requires specific attention if rework is to be reduced on-site. The analysis indicated that design management and procurement strategies identified were not being implemented effectively, even though they are considered to be strategies that can reduce client initiated changes, design iterations, and errors.
If incidence of rework is to be reduced, then it is necessary to reexamine the work practices and methods used to deliver projects. The adoption of a multidisciplinary team approach to the production and management of contract documentation could reduce errors and the potential for client initiated changes [33]. Rather than working in a sequential manner to design and produce the project's design and contract documentation, and identify materials and equipment required for production, project participants should work together in a concurrent manner and, therefore, improve their understanding, coordination, and communication with one another.

With the aim of reducing client initiated changes, stimulating the adoption of VM, and improving the production and management of contract documentation through the use of information technology, an alternative procurement model that places emphasis on rework reduction is presented in Fig. 3. 
Here, each member of the team is assumed to have a direct contact with the client during the various stages of the design and production process so that they can be guided about the selection of alternative design solutions/construction sequencing and informed about the cost ramifications of initiating changes. The procurement structure has been designed to stimulate teamwork, as this is considered a critical attribute for the effective management of information in projects [36]. In fact, when team members have a share in the development of the project they tend to perform better, which may have a positive effect on limiting design iterations, variations, and sacrifices in quality [36], [42].

\section{A. Design Development}

Previous research suggests that when a client organization employs an independent project facilitator, interorganizational communication between project participants can be effectively stimulated and developed [49]. In this instance, the project facilitator would be responsible for identifying the client's strategic needs, and initiating and managing the design process so that changes are minimized and, thus, do not influence the documentation process (Fig. 3). Findings from the survey clearly reveal that the contract documentation process is an area that needs a considerable amount of attention, so it is necessary that the client commission an experienced project facilitator to effectively plan, organize, lead, and control the project this phase of the project [54].

Considering the significance of VM as strategy for reducing rework, it should be undertaken prior to the production of the detailed design and documentation stage of the project so as to minimize the impact of any change orders, which may be initiated by the client at a later stage (Fig. 3). In addition, the VM study can enable the project team, which at this point will include the design consultants, QS, main contractor, and service subcontractors, to evaluate the project's functionality, cost, constructability, and method of construction.

Auditing and Sign Off: As the project progresses through the various stages of design development, as noted in Fig. 3, the project facilitator should undertake an audit and sign off at the end of each design stage so as to make sure that what has been specified by the client has been in-built into the design and is documented accordingly. In doing so, minimizing the potential for client initiated changes.

Though, it should be noted that the regression analysis revealed that design scope freezing can contribute to rework as it may conflict with meeting client requirements. When clients or occupiers, especially inexperienced clients, are confronted with a design scope freeze, they may feel intimidated, as it could reduce their decision-making flexibility about their final investment.

The auditing process identified in Fig. 3 should also form an integral part of a benchmarking process. The establishment of a series of rework benchmarks at specific interfaces could be used to enable industry clients, who procure buildings on a regular basis, and project participants to compare predefined metrics against what has been found to be best practice performance.

After an audit has been undertaken, it is recommended that the client be given the opportunity to sign off on a complete set of documentation (Fig. 3). If the documentation is considered acceptable to the client, then a detailed review is undertaken to make sure that there are no errors or omissions are present. This will be followed by client and project team signing off on the agreed set drawing set, which should result in any ambiguity of intention being avoided. If changes are required later in the project, then they are reviewed and authorized using a systematic and structured scope and change program.

Selection Processes: Traditional price-driven selection procedures would not be used as they may limit the flexibility of the designers and contractors to explore innovative avenues that can result in optimal performance. Furthermore, traditional price-driven selection procedures are deemed to be ineffective, as they used to ensure that clients procure their buildings for the least possible cost but for a less than best product [26]. Ideally, the project team should be selected from weighted prequalification criteria, past performance, and through the process of negotiation. For example, a reputable designer would be awarded increased weightings for certain criteria such as experience, qualifications of personnel, quality-of-service provided, quality management, current workload, strategic alliances, and so on [54]. The design consultants with the highest aggregate weighting should then be selected and, subsequently, a fee would be negotiated after the parameters for their scope of work for the project are established. These are extremely important issues to bear in mind, as low fees and inadequate time to prepare documentation were identified in the analysis as perceived causes of rework by designer consultants.

Contractors who have the capability of undertaking the project or who have previously worked with the project facilitator and/or the design consultants would be selected in a similar manner, though their input will not be required until the concept and schematic stage had been completed. The contractor may also be given the opportunity to recommend to the client key subcontractors (e.g., mechanical and electrical) and suppliers with whom they had formed a strategic alliance to be involved within the project at this stage. However, the client would need to specify to the subcontractors and suppliers that their expertise was being sought at this point and they would be paid a nominal fee for their input. No guarantee of being selected for the project should be provided to the subcontractor and suppliers. Implicitly, however, having prior knowledge about the needs and requirements of the project would be an advantage at the time of tender.

A client who builds on a regular basis could specify that consultants will be benchmarked, especially for the quality of the contract documentation that they produce, so as to provide a mechanism for monitoring their performance. Incentives, such as repeat work or a possible share in cost savings that are attained could be used as a basis for encouraging an ameliorated level of service quality. By using the same project team members where possible, a "partnering culture" founded on cooperation and teamwork could be allowed to ripen and flourish [31].

This would provide a paradigm for collective learning, identified in Fig. 3, to take place within the project. That is, the project team would develop knowledge by working as a whole. Moreover, individuals within the team could learn about themselves and their team members' requirements. Over time, the project 
team members would learn from each other and develop new skills and capabilities that would alter what they can do and understand. In doing so, the project team would learn to learn together.

Tools and Techniques: In addressing the issues relating to information technology and improved scoping of client requirements, a number of tools and techniques can be utilized to reduce the incidence of rework. Tools such as the analytical design planning technique (ADePT), which utilizes the design structure matrix [50] can be used to identify missing information, variations in the quality of information exchange between participants and, therefore, preventing costly design iterations [7]. Essentially, ADePT focuses on efficient planning and management of design by scheduling design tasks on the basis of their information requirements and, thus, is able to produce a detailed program of the optimized design process. Prior to, and during, the commencement of the detailed design and documentation phase of the project, individual project team members would be responsible for the following.

- The architect would present ideas on how the client's requirements can be met aesthetically and functionally and provide the detailed design documentation.

- The engineers would design and develop the structural and services capabilities required and in conjunction with the architect provide detailed design documentation.

- The QS would produce cost plans, undertake life-cycle costing analysis and cost checks as the design developed through its various stages.

- The contractor and subcontractors (including hydraulics, mechanical, and electrical subcontractors) would develop and plan workable production strategies, schedules, work methods using the last planner concept.

- The key suppliers would propose material and equipment alternatives.

- The property and marketing specialists organize tenant's or purchasers.

To better understand the client's requirements and improve communication between project team members, quality function deployment (QFD) should be used as the principal technique for translating customer requirements. The QFD process begins by analyzing and listening to customers to determine the characteristics of the products. Through detailed discussion during the design process each customer's needs and preferences are defined and broken down into categories called customer attributes. Customer attribute information forms the basis for a matrix called the house of quality. By building a matrix of customer requirements, the multidisciplinary team can use customer feedback to make design, engineering, and production decisions. The matrix assists the team to translate customer attribute information into specific operating goals. The important product characteristics and goals for improvement are jointly agreed on and detailed in the house of quality matrix. This process encourages the different disciplines to work closely together and results in a better understanding of one another's goals: ultimately, the team becomes customer focused [28].

To improve the efficiency and effectiveness of the documentation process, the project team should be encouraged to use com- puter-aided design/engineering (CAD/CAE) technologies. By using $\mathrm{CAD} / \mathrm{CAE}$ databases, the design and documentation can be accessed, albeit limited, by different team members. There must, however, be a convenient platform on which different organizations involved can work and communicate simultaneously. For example, in the case of architects and engineers, this platform could be an advanced form of CAD/CAE, which has solid and parametric modeling capabilities. Increasing evidence suggests that utilizing $\mathrm{CAD} / \mathrm{CAE}$ can lead to major reductions in design-related rework and design time [5], [29]. Information technology applications should also be used to support communication and information transfer, exchange, retrieval, and storage throughout the production process. This would improve the quality of documentation that is produced and minimize effort and time during the design review and checking process.

\section{B. Production Process}

The analysis revealed that the design process requires the most significant amount of attention if rework is to be reduced. However, it is important that the contractor uses their understanding of constructability and knowledge acquired from the design process to plan and coordinate the works so that subcontractors know "when and where" they are supposed to conduct their tasks. The use of a novated contractual arrangement, whereby the architect and engineering consultants contract with the client is discharged and substituted with a contract with the contractor, would enable the contractor to manage the design team and, thus, ensure that constructability formed an integral part of the building's design. Design consultants can be novated to the contractor when the design is anywhere from $20 \%$ to $80 \%$ complete [12]. In doing so, the main contractor would accept the risk and assume single-point responsibility for the project. At this point, it is proposed that a QS would act in an advisory capacity to the client, project facilitator, and main contractor. It is envisaged that the main contractor would offer a guaranteed maximum price to complete the project with any savings shared between themselves, the client and possibly the designers, key subcontractors, and suppliers.

The key subcontractors and suppliers would be asked to submit a competitive price to undertake the work. In this case, the QS would act as an auditor for the client, and would have preliminary benchmarks for the cost of the works to be undertaken. The main contractor would be responsible for selecting the remaining subcontractors and suppliers, although it is suggested that those who the main contractor had formed a strategic alliance with would be preferred.

\section{CONCLUSION}

The research presented in this paper offers a holistic rework reduction model based upon empirical findings. In addition, it provides a platform for further research, specifically, in the context of design management and the organization and management of construction projects. The research has demonstrated that there were no significant differences in respondents' estimates of rework costs, which implies that the mean TRCs (direct and indirect) of $12 \%$ are a reasonable assessment of that experienced in the projects sampled. 
Using the multivariate technique of stepwise multiple regression enabled the significant factors that contribute to rework to be identified. Changes initiated by a client or occupier when a product or process had been completed and design scope freezing were factors identified as contributing to rework. Previous research has indicated that design scope freezing is an effective strategy for reducing change orders; however, it would appear that it can also contribute to rework occurring during construction, especially, if inexperienced participants are advised to implement this strategy. Value management and the effective use of information technology during the design process were found to be factors that could significantly reduce rework costs.

The procurement model that was proposed is not radically different from some of the forms of design and construct that are currently being used today. Fundamentally, the difference lays in the composition of the design team and the reliance on teamwork. The authors suggest that the proposed model should be client-driven, that is, by either public or experienced private clients. Therefore, it is necessary they are educated about the potential to reduce the cost and time of their projects. If a significant reduction in rework can be achieved, then clients may well invest these savings in other facilities and perhaps use the same team. Furthermore, once a project team has been established, the project manager could market their success to attract the business of small and occasional clients who typically seek the advice of an architect. Again, if substantial savings are made then their confidence in construction may be augmented. Once experienced clients have acquired the benefits of the proposed model, then small and occasional clients will follow suit. As a result, this may significantly improve the performance and productivity of the construction industry and its contribution to gross domestic product.

APPENDIX A

\section{QUESTIONNAIRE SCALE}

\section{Design Changes}

Changes made at the request of the contract during construction

Changes made at the request of the client

Changes made at the request of an end user/regulatory body

Revisions, modifications of the design initiated by the contractor/subcontractor

Errors in the contract documentation

Omissions of items from the contract documentation

\section{Construction Changes}

Changes in construction method to improve constructability

Changes in construction method due to site conditions

Changes initiated by the client/occupier after work had been undertaken

"Ditto" after a product/process has been completed Changes made during the manufacture of a product Changes initiated by the contractor to improve quality

Errors due to inappropriate construction methods
Omissions of some activity of task

Damage caused by a subcontractor

\section{Client}

Lack of knowledge of the D\&C process

Lack of funding allocated for site investigations

Lack of client involvement in the project

Inadequate time and money spent on the briefing process

Poor communication with design consultants

Payment of low fees for preparing contract documentation

\section{Design Team}

Ineffective use of quality management practices

Ineffective use of IT

Poor coordination of design team members

Time boxing

Poor planning of workload

Lack of manpower to complete tasks

Staff turnover/reallocation to other projects

Incomplete design at the time of tender

Insufficient time to prepare contract documentation

Inadequate client brief to prepare detailed documentation

\section{Site Management}

Ineffective use of quality management practices

Ineffective use IT

Setting out errors

Poor planning and coordination of resources

Staff turnover/reallocation to other projects

Failure to provide protection to the works

\section{Subcontractor}

Ineffective use of quality management practices

Damage to other trades due to carelessness

Inadequate managerial and supervisory skills

Low labour skills level

Use of poor materials

\section{Project Scope}

Changes were documented and issued to respective parties on a regular basis

Project scope was reevaluated before the project was documented

Project scope definition was resolved before the project commenced

End-users were involved in the development of scope

Client had a disciplined approach to decision-making

\section{Contract Documentation}

Contract documentation was of a high standard

Contract documentation was cross-checked to ensure changes, were coordinated

Contract documentation was prepared by inexperienced personnel

Design reviews and verifications were undertaken

An assessment of the status of the design and the potential for change was provided to the contractor

\section{Project Communication}

Client's needs and priorities were communicated to the project team

The specification for the performance and quality requirements for the building were clearly defined 
Roles and responsibilities of the project team were defined in terms of milestones

Working procedures and communication lines were clearly defined

Requests for information were answered in a timely manner

Any change/error/omission that was identified was immediately reported and acted upon

\section{Procurement Strategy}

Contractual incentives

Project quality management system

Prequalification

Relational contracting

Bills of quantities (ASMM 5)

\section{Design Management}

Value management

Design for construction

Computer visualization

Involvement of subc/suppliers during design

Constructability analysis

Design scope freezing

Team building

\section{ACKNOWLEDGMENT}

The authors would like to thank the Editor-in-Chief, Prof. G. F. Farris, the Departmental Editor, Prof. J. Pinto, the Editorial Assistant Y.-Y. Chen, and anonymous reviewers for their encouragement and comments on earlier versions of this manuscript.

\section{REFERENCES}

[1] H. Abdul-Rahman, "The management and cost of quality for civil engineering projects," Ph.D. dissertation, Univ. Manchester Inst. Sci. Technol. (UMIST), Manchester, U.K., 1993.

[2] F. Ackermann, C. Eden, and T. Williams, "Modeling litigation: Mixing qualitative and quantitative approaches," Interfaces, vol. 27, no. 2, pp. 48-65, 1997.

[3] P. L. Alreck and R. B. Settle, The Survey Research Handbook. Homewood, IL: Richard D. Irwin, 1985.

[4] J. L. Ashford, The Management of Quality in Construction. London, U.K.: E \& F Spon, 1992.

[5] C. J. Anumba and L. N. Newnham, "Computer-based collaborative building design: Conceptual model," Inte. J. Construction Inform. Technol., vol. 8, no. 1, pp. 1-14, 2000.

[6] Australian Procurement and Construction Council (APCC), Construct Australia: Building a Better Construction Industry in Australia. Deakin West, ACT, Australia: The Australian Procurement and Construction Council Inc., 1999.

[7] S. Austin, A. Baldwin, B. Li, and P. Waskett, "Analytical design planning technique (ADePT): A dependency structure matrix tool to schedule the building design process," Construction Manage. Econ., vol. 18, no. 2, pp. 173-182, 2000.

[8] P. Barber, D. Sheath, C. Tomkins, and A. Graves, "The cost of quality failures in major civil engineering projects," Int. J. Qual. Rel. Manage., vol. 17, no. 4/5, pp. 479-492, 2000.

[9] Building Research Establishment, Quality Control on Building Sites. Garston, U.K.: BRE, 1981.

[10] J. Burati and J. Farrington, "Cost of quality deviations in design and construction," Univ. Texas at Austin, Austin, TX, Rep. Construction Ind. Inst., 1987.

[11] G. Burroughs, Concrete Quality Assurance: The Contractors Role. Melbourne, Australia: Quality Assurance in the Construction Industry, Concrete Inst. Australia, Sept. 1993.
[12] A. P. C. Chan, "Evaluation of novation contract," in Proc. National Construction Management Conf.. Sydney, Australia, Feb. 17-18, 1994, pp. 383-396.

[13] M. Cnudde, "Lack of quality in construction-economic losses," in Proc. Eur. Symp. Management, Quality, Economics in Housing and Other Building Sectors, Lisbon, Portugal, Sept. 30-Oct. 4 1991, pp. 508-515.

[14] Construction Industry Development Agency (CIDA), "A report on the time and cost performance of Australian building projects completed 1988-1993," CIDA and Masters Builders Australia, Sydney, Australia, 1993.

[15] —, Measuring Up or Muddling Through: Best Practice in the Australian Non-Residential Construction Industry. Sydney, Australia: CIDA and Masters Builders Australia, 1995.

[16] Construction Industry Institute (CII), The Impact of Changes on Construction Cost and Schedule. Austin, TX: Univ. Texas at Austin, Apr. 6-10, 1990.

[17] K. G. Cooper, "The rework cycle: Benchmarking for the project manager," Project Manage. J., vol. 24, no. 1, pp. 17-22, 1993.

[18] L. J. Cronbach, "Coefficient alpha and the internal structure of tests," Psychometrika, vol. 16, pp. 297-334, 1951 .

[19] I. D. Cox, J. Morris, J. H. Rogerson, and G. E. Jared, "A quantitative study of post contract award design changes in construction," Construc tion Manage. Econ., vol. 17, no. 4, pp. 427-439, 1999.

[20] Department of Industry, Science and Tourism (DISR), "A report for government by the national building and construction committee," DISR, Canberra, Australia, Building for Growth: An Action Agenda for the Building and Construction Industries, 1999.

[21] C. Eden, T. Williams, and S. Howick, "The role of feedback dynamics in disruption and delay on the nature of disruption and delay (D\&D) in major projects," J. Oper. Res. Soc., vol. 51, no. 3, pp. 291-300, 2000.

[22] O. O. Faniran, P. E. D. Love, and H. Li, "Optimal allocation of construction planning resources," ASCE J. Construction, Eng. Manage., vol. 125, no. 5, pp. 311-319, 1999.

[23] J. Gardiner, "Management of design documentation, where do we go from here?," in Construction and Management, Recent Advances, R. R. Wakefield and D. G. Carmichael, Eds. Rotterdam: Balkema, 1994, pp. 113-118.

[24] P. Gluch and P.-E. Josephson, "Evaluation of methods for studying environmental errors in building and civil engineering projects," in Proc. Nordic Seminar Construction Economics and Organization. Göteborg, Sweden: Chalmers Univ. Technol., Apr. 12-13, 1999, pp. 137-144.

[25] R. Gyles, Royal commission into productivity in the building industry in New South Wales, Sydney, Australia, vol. 1-10, 1992.

[26] G. D. Holt, D. Proverbs, and P. E. D. Love, "Survey findings on U.K. construction procurement: Is it achieving lowest cost, or value?," Asia-Pacific Building Construction Manage. J., vol. 5, no. 2, pp. 13-20, 2000.

[27] P.-E. Josephson and Y. Hammarlund, "The causes and costs of defects in construction. A study of seven building projects," Automat. Construction, vol. 8, no. 6, pp. 642-681, 1999.

[28] J. M. Karma, "Client requirements processing for concurrent life-cycle design and construction," Ph.D. dissertation, Univ. Teeside, Newcastle, U.K., 1999.

[29] J. M. Karma, C. J. Anumba, and N. F. O. Evbuomwan, "Developments in the implementation of concurrent engineering in construction," Comput.-Integrated Design and Construction, vol. 2, no. 1, pp. 68-78, 2000.

[30] H. Li and P. E. D. Love, "Visualization of building interior design to reduce rework," in Proc. Int. Conf. Information Visualization. London, U.K.: School of Oriental and African Studies, Univ. London, July 29-31, 1998, pp. 187-191.

[31] H. Li, E. W. L. Cheng, and P. E. D. Love, "Partnering research in construction," Eng. Construction Arch. Manage., vol. 7, no. 1, pp. 76-92, 2000.

[32] K. Lomas, Quality Pays: Engineers Australia, Feb. 1996, p. 26.

[33] P. E. D. Love, "The influence of project type and procurement method on rework costs in building construction projects," ASCE J. Construction Eng. Manage., vol. 128, no. 1, pp. 18-29, 2002.

[34] — "Auditing the indirect consequences of rework in construction: A case based approach," Manage. Auditing J., vol. 17, no. 3, 2002. 
[35] P. E. D. Love and J. Smith, "Bench-marking, bench-action and benchlearning: Rework mitigation in projects," ASCE J. Manage. Eng., vol. 19, no. 4, pp. 147-159, 2003.

[36] P. E. D. Love, A. Gunasekaran, and H. Li, "Concurrent engineering: A strategy for procuring construction projects," Int. J. Proj. Manage., vol. 16, no. 6, pp. 375-383, 1998.

[37] P. E. D. Love, H. Li, and P. Mandal, "Rework: A symptom of a dysfunctional supply chain," Eur. J. Purchasing and Supply Manage., vol. 5, no. 1, pp. 1-11, 1999.

[38] P. E. D. Love, J. Smith, and H. Li, "The propagation of rework benchmark metrics for construction,” Int. J. Qual. Rel. Manage., vol. 16, no. 7, pp. 638-658, 1999.

[39] P. E. D. Love, P. Mandal, and H. Li, "Determining the causal structure of rework in construction projects," Construction Manage. Econ., vol. 17, no. 4, pp. 505-517, 1999.

[40] D. McGeorge and A. Palmer, Construction Management: New Directions. Melbourne, Australia: Blackwell Sci., 1997.

[41] Nat. Economic Development Office, Achieving quality on building sites, pp. 18-19, 1987.

[42] J.-L. Nesan and G. D. Holt, Empowerment in Construction: The Way Forward for Performance Improvement. Hertfordshire, U.K.: Somerset Res. Studies Press, 1999.

[43] NWPC and NBCC, "No dispute-strategies for improvement in the Australian building and construction industry," Nat. Public Works Conf. Nat. Build. Construction Council Joint Working Party Rep., Canberra, ACT, Australia, May 1990.

[44] J. T. O'Connor, "Impacts of constructability improvement," ASCE $J$. Construction Eng. Manage., vol. 111, no. 4, pp. 404-410, 1985.

[45] J. O. Rawlings, Applied Regression Analysis-A Research Tool. Belmont, CA: Wadsworth and Brooks/Cole, 1988.

[46] G. Rounce, "Quality, waste, and cost consideration in architectural building design management," Int. J. Proj. Manage., vol. 16, no. 2, pp. 123-127, 1998.

[47] J. Rudolph, "Quality management and rework in the construction industry," M.S. thesis, Virginia Polytech. Inst. State Univ., Blacksburg, VA, 1992.

[48] A. C. Sidwell, "A critical study of project team organizational forms within the building process," Ph.D. dissertation, Univ. Aston, Birmingham, U.K., 1982.

[49] J. Smith and N. Jackson, "Strategic needs analysis: Its role in brief development," Facilities, vol. 18, no. 13/14, pp. 502-512, 2000.

[50] D. V. Steward, "The design structure system: A method for managing the design of complex systems," IEEE Trans. Eng. Manage., vol. TEM-1, pp. 71-74, 1981.

[51] B. Tabachnick and L. S. Fidell, Using Multivariate Statistics, 3rd ed. New York: Harper Collins, 1996.

[52] Construction Management Committee of the ASCE Construction Division, "Constructability and constructability programs: While paper," ASCE J. Construction Eng. Manage., vol. 117, no. 1, pp. 67-89, 1991.

[53] H. R. Thomas and C. Neapolitan, "The effects of changes on labour productivity: Why and how much?," The Pennsylvania State Univ., University Park, PA, Rep. Construction Industry Institute, Source Document 94, 1994

[54] C. H. Wong, G. D. Holt, and P. T. Harris, "Prequalification criteria-A survey of U.K. construction practitioners' opinions," J. Construction Res., vol. 2, no. 1, pp. 41-56, 2001.

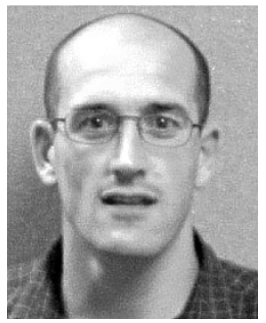

Peter E. D. Love received the M.Sc. degree in construction project management from the University of Bath, Bath, U.K., and the Ph.D. degree in operations management from Monash University, Victoria, Australia.

$\mathrm{He}$ is a Chair Professor of Project Management and Information Systems in the School of Management Information Systems, Edith Cowan University, Perth, Australia. He has a wide range of industry experience, which he gained in the U.K. and Australia working as a consultant project manager and a commercial manager for a multinational contracting organization. $\mathrm{He}$ has coauthored/edited five books and has authored/coauthored over 300 internationally refereed research papers, which have appeared in journals such as the European Journal of Operational Research, European Journal of Information Systems, Journal of Management Information Systems, Information and Management, International Journal of Production Economics, International Journal of Operations and Production Management, Project Management Journal, International Journal of Project Management, and the Asia-Pacific Editor for the Journal of Enterprise Information Management. His research interests include supply chain management, quality management, IS project management, and strategic information systems evaluation.

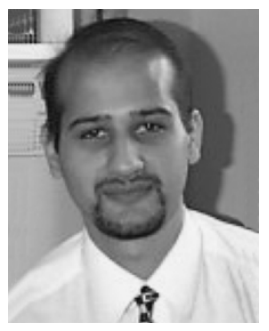

Zahir Irani is a Chair Professor in Information Systems Evaluation in the Department of Information Systems and Computing, Brunel University, Middlesex, U.K. Having worked for several years as a Project Manager, he retains close links with industry, and is a nonexecutive director to a leading "blue-chip" company, and consults with organizations such as Glaxo Wellcome, BMW (U.K.) Ltd., and Adidas. He serves as a nonexecutive member to an international academic advisory group for MCB University Press, and is a Member of the Editorial Board of Butterworth Heinemann/Computer Weekly-Professional Information Systems Text Books series. He is a Visiting Scholar to the University of Salford, Manchester, U.K. and has acted as Visiting Professor to Edith Cowan University, Perth, Australia, Deakin University, Victoria, Australia, and the Hong Kong Polytechnic University. He is the Editor-in-Chief of the Journal of Enterprise Information Management. He has coauthored a textbook on information systems evaluation, and written over 200 internationally refereed papers, which have appeared in journals such as the European Journal of Operational Research, European Journal of Information Systems, Journal of Management Information Systems, Information and Management, International Journal of Production Economics, and International Journal of Operations and Production Management.

David J. Edwards is a Lecturer in off-highway plant and equipment management, Loughborough University, Leicestershire, U.K. He is currently undertaking research contracts for the Engineering and Physical Sciences Research Council, JCB, Defence Logistics Organization (U.K. Ministry of Defense), Contractors Mechanical Plant Engineers, and other leading industrial organizations. He is also the sole academic representative on a Specialist Health and Safety Commission's Panel for workplace transport accidents and Founder of the Off-highway Plant and Equipment Research Centre (OPERC). He has published more than 100 refereed research papers, four textbooks, and numerous other publications including trade journal articles and conference papers. He is a peer referee for 16 leading academic journals and to date, he has secured more than $£ 500000$ in research funding. 